Paweł Beyga ${ }^{1}$

Papieski Wydział Teologiczny we Wrocławiu

\title{
Selected Doctrinal Arguments against the Admission of Persons of Homosexual Orientation to the Sacrament of Holy Orders
}

Since the 1960s, there has been a dispute about human sexuality, sexual orientation and attitudes towards this sphere of human life in general. The cultural changes brought about by, among other things, the moral revolution after 1968 have resulted in a profound social revision of the traditional view of marriage, family and human sexuality. ${ }^{2}$ However, the belief that these discussions bypass Christianity needs to be dispelled. Even among believers in Christ, a debate is currently under way regarding attitudes towards homosexual orientation and same-sex cohabitation. This ongoing discussion and the attendant tensions are evidenced by the fact that the Anglican Communion decided to admit to presbyteral and episcopal ordination people who openly declare their homosexuality. A number of Anglicans were disappointed by the 1993 decisions of the General Synod of the Church of England on the ordination of women, ${ }^{3}$ the undermining of the doctrine of the existence of hell in 1995, the election of an openly homosexual Gene Robinson as a bishop in New Hampshire in the United States and by the

${ }^{1}$ Pawel Beyga - doctor of theology (dogmatic theology) of the Pontifical Faculty of Theology in Wrocław, member of the Society of Dogmatic Theologians, editorial secretary of the Polish version of the International Theological Review "Communio"; e-mail: pbeyga@wp.pl. ORCID: 0000-0002-0838-9482.

${ }^{2}$ Yves Chiron writes about the impact of the so-called ' 68 revolution on the Church in France in his book: Rewolucja 68. Swąd szatana w Kościele, thum. M. Żurowska, Kraków 2021.

${ }^{3}$ Cf. A. Napiórkowski, Między ekumenizmem a konwertyzmem. Kościót rzymskokatolicki a Kościót anglikański [in:] Dialog ekumeniczny a missio Ecclesiae, red. M. Chojnacki, J. Morawa, A. Napiórkowski, Kraków 2011, p. 46. 
liberalisation of moral teaching, ${ }^{4}$ The formation of the Traditional Anglican Communion $^{5}$ in the early 1990s and the conversion of some Anglicans to the Catholic Church enabled by under the document Anglicanorum coetibus was the aftermath of those decisions. ${ }^{6}$

A preliminary description of the tensions arising in the Catholic Church against this background on a European scale may only be addressed by a doctoral dissertation or a larger monograph. This paper reduces the problem to the question: what doctrinal arguments are behind the Holy See's current decision not to admit men with a firmly rooted homosexual orientation to the sacrament of Holy Orders? It is moral theologians who usually address the topic of homosexuality; yet, the problem should also be taken up by dogmatic theology. After all, this is about the sacrament of Holy Orders, which is the subject of sacramentology. The problem can be solved in three stages: the presentation of selected contents of the documents of the Holy See in the $20^{\text {th }}$ and $21^{\text {st }}$ centuries, the analysis of their doctrinal threads and the evaluation of their reception in the light of current challenges. We will also invoke the opinion of recent popes, who have had to face new problems within the Catholic Church. At present, Polish theology lacks research on homosexuality and the vocation to priesthood, while such scrutiny has been conducted for years in other countries. We should mention, for example, the names of such authors as Jason Berry, Daniel Cozzens and Charles Churran. These thinkers did not always present a Catholic stance on these issues in their works, but they were certainly not afraid to address them. Among them was Dariusz Oko who took up this issue in his latest publication devoted to the so-called 'Lavender Mafia'. ' One can, of course, discuss whether the term 'mafia' is proper in this context and whether this expression can be used in academic discourse, but the publication itself should be seen as a bold attempt to address this issue by an academic from the circle of Polish theologians and philosophers.

${ }^{4}$ Cf. A. Nadbrzeżny, Unia czy wspólnota z Rzymem? Pytanie o model jedności chrześcijan w konstytucji apostolskiej Benedykta XVI „Anglicanorum coetibus”, “Studia Salvatoriana Polonica" 4 (2010), p. 42-43.

${ }^{5}$ Cf. D. Bruncz, Wspólnota anglikańska po Konferencji Lambeth 2008, "Ecumenical Studies and Documents" 63 (2008) 2, p. 86.

${ }^{6} \mathrm{Cf}$. P. Beyga, Tradycja anglikańska $w$ mszale dla ordynariatów personalnych bytych anglikanów, Opole 2018.

7 Cf. D. Oko, Lawendowa mafia. Z papieżami i biskupami przeciwko homoklikom w Kościele, Kraków 2020. 


\section{Documents of the Holy See}

The problem of homosexuality in the ranks of Catholic presbyters is not something new in the Church. ${ }^{8}$ In this respect a passage from the 1568 document Horrendum illud scelus of Pius $\mathrm{V}$ is well worth quoting. 'So that the contagion of such a grave offense may not advance with greater audacity by taking advantage of impunity, which is the greatest incitement to sin,' wrote this Pope of the Counter-Reformation era, 'and so as to more severely punish the clerics who are guilty of this nefarious crime and who are not frightened by the death of their souls, we determine that they should be handed over to the severity of the secular authority, which enforces civil law'. ${ }^{9}$ Leaving aside the criminalisation of homosexual acts implied by Pius V, it is important to note this Pope's determination to fight homosexuality within the ranks of the Roman Catholic clergy. This shows that the problem had already arisen and been severely judged several centuries earlier by the bishops of Rome. Long before Pius V, this issue was dealt with by Peter Damian in his 1049 study Liber Gomorrhianus. ${ }^{10}$

The beginning of the last century brings to our attention Crimen sollicitationis, the secret 1922 Holy Office instruction. This document, although it dealt with the crime of inciting sexual acts during or in the context of the sacrament of penance and reconciliation (solicitation), implicitly assumed also the sin of homosexual acts in similar circumstances. In the $20^{\text {th }}$ century, the first document which explicitly dealt with the problem of ordination for men of homosexual orientation was the instruction Religiosorum institutio. According to Andrzej Kobylinski, this instruction was printed in the Latin version by the Congregation for Religious on 2 February 1961, and two years later it was published in English in the United States. However, for unknown reasons, it was never published in the Acta Apostolicae Sedis and thus, paradoxically, this document with the approval of John XXIII never came into force. ${ }^{11}$ The most important part of Religiosorum institutio explicitly states that homosexuals and those with a tendency to pederasty must not be admitted to religious vows or to the sacrament of Holy Orders. ${ }^{12}$

${ }^{8}$ Resignation from the clerical state in the ancient Church due to grave sins is described in the text: H. Pietras, Dymisja ze stanu duchownego i jej skutki w starożytności chrześcijańskiej [in:] Odejścia od kapłaństwa. Studium historyczno-psychologiczne, red. K. Dyrek, Kraków 2010, pp. 7-19.

9 Pius V, The Bull Horrendum illud scelus (1568), https://www.rkdocumenten.nl/rkdocs/index. php?mi $=600 \&$ doc $=7021$ [accessed: 12.2 .2021$]$.

${ }^{10}$ Cf. Piotr Damiani, Księga Gomory [in:] K. Skwierczyński, Piotra Damianiego „Księga Gomory" i walka z sodomia wśród kleru, Kraków 2011, pp. 257-309.

${ }^{11}$ Cf. A. Kobyliński, Homoseksualizm i kaptaństwo w Kościele katolickim na przestrzeni wieków, "Przegląd Historyczny" 109 (2018) 2, pp. 286-287.

12 'Advantage to religious vows and ordination should be barred to those who are afflicted with evil tendencies to homosexuality or pederasty, since for them the common life and the 
The reason given was pragmatic, i.e. such inclinations would pose a danger to monks and priests themselves and to the faithful entrusted to them. However, this document was forgotten in the Catholic Church for several decades and was rediscovered when the sex scandals in the Church in the United States came to light at the beginning of the $21^{\text {st }}$ century.

The problem of sexual identity was addressed many years later in Potissimum Institutioni, the instruction on the manner of the formation of candidates for religious orders. According to the authors of this 1990 document:

Future religious should thus be offered the possibility of reflecting on the role of sexuality in the divine plan of creation and salvation. In this context reasons must be given and understood to explain why those who do not seem to be able to overcome their homosexual tendencies, or who maintain that it is possible to adopt a third way, living in an ambiguous state between celibacy and marriage must be dismissed from the religious life. ${ }^{13}$

It is worth noting here that 'the key sentence concerning homosexual tendencies has been formulated differently in the official translations of this document. For example, the Polish and English versions speak of overcoming homosexual inclinations [...], while the Italian and Spanish translations speak of controlling homosexual inclinations [...]. ${ }^{14}$ It is one thing to overcome homosexual inclinations completely, but it is quite another to control them. One could ask: did the congregation mean the renunciation of homosexuality or permanent sexual abstinence? These questions remain to be answered.

Instruction Concerning the Criteria for the Discernment of Vocations with Regard to Persons with Homosexual Tendencies in View of Their Admission to the Seminary and to Holy Orders was a longer 2005 text entirely devoted to the relationship between homosexuality and priesthood. This document had been in preparation for many years and was sparked by the events that shocked public opinion in the United States after the revelation of the scale of paedophilia in the American Church in the early $21^{\text {st }}$ century. In the first year of the pontificate of Benedict XVI, the Holy See found it necessary to point out that

priestly ministry would constitute serious dangers'. Cf. Sacred Congregation For Religious, Instruction on the Careful Selection And Training Of Candidates For The States Of Perfection And Sacred Orders Religiosorum institutio (1961), 4. https://www.papalencyclicals.net/john23/j23religios.htm [accessed: 22.11.2020].

13 The Congregation for Institutes of Consecrated Life and Societies of Apostolic Life, Directives on Formation in Religious Institutes Potissimum Institutioni (1990), 39. https://www.vatican. va/roman_curia/congregations/ccscrlife/documents/rc_con_ccscrlife_doc_02021990_directiveson-formation_en.html [accessed: 12.2.2021].

${ }^{14}$ A. Kobyliński, Homoseksualizm i kaptaństwo..., p. 290. 
in the light of such teaching, this Dicastery, in accord with the Congregation for Divine Worship and the Discipline of the Sacraments, believes it is necessary to state clearly that the Church, while profoundly respecting the persons in question, cannot admit to the seminary or to holy orders those who practise homosexuality, present deep-seated homosexual tendencies or support the so-called 'gay culture'. Such persons, in fact, find themselves in a situation that gravely hinders them from relating correctly to men and women. One must in no way overlook the negative consequences that can derive from the ordination of persons with deepseated homosexual tendencies. ${ }^{15}$

In addition to this strong statement, the Congregation for Catholic Education has also presented a theological justification for such practical solutions. The 2005 document is also important because it is the first time in modern times that homosexual tendencies, and not only homosexual acts, were recognised as an obstacle to ordination. The above-mentioned documents argue against the ordination of homosexual men as presbyters primarily on pragmatic grounds: their inappropriate relationship to men and women and the possible resultant negative consequences.

At this point Benedict XVI's statement from an interview with German journalist Peter Seewald comes to our attention:

Homosexuality is incompatible with the priestly vocation. Otherwise, celibacy itself would lose its meaning as a renunciation. It would be extremely dangerous if celibacy became a sort of pretext for bringing people into the priesthood who don't want to get married anyway. For, in the end, their attitude toward man or woman is somehow distorted, off-centre, and, in any case, is not within the direction of creation of which we have spoken. ${ }^{16}$

The voice of the current Pope Emeritus is extremely important. These words may be an apt commentary on a document that was, after all, published at his behest. During his almost eight-year pontificate, decisive steps were taken, also in the form of clear documents, to show the position of the Church towards homosexuals wishing to receive the sacrament of Holy Orders. It is worth noting that

15 The Congregation for Catholic Education, Instruction Concerning the Criteria for the Discernment of Vocations with regard to Persons with Homosexual Tendencies in view of their Admission to the Seminary and to Holy_Orders (2005). http://www.vatican.va/roman_curia/congregations/ccatheduc/documents/rc_con_ccatheduc_doc_20051104_istruzione_en.html [accessed: 12.2.2021].

${ }^{16}$ Benedict XVI, P. Seewald, Light of the World: The Pope, the Church and the Signs of the Times, San Francisco 2010, pp. 151-152. 
this happened despite the crisis in vocations to the priesthood in the countries of Western Europe and America. ${ }^{17}$

\section{Selected Doctrinal Themes}

In order to properly understand the documents of the Holy See on not allowing homosexual persons to be ordained, it is necessary to look at the Church's teaching on homosexual inclinations and acts expressed in the Catechism of the Catholic Church. The very placement of this topic in the context of the Christian understanding of chastity allows for a proper perspective on this issue. According to the authors of the catechism,

Homosexuality refers to relations between men or between women who experience an exclusive or predominant sexual attraction toward persons of the same sex. [...] Its psychological genesis remains largely unexplained. Basing itself on Sacred Scripture, which presents homosexual acts as acts of grave depravity, tradition has always declared that 'homosexual acts are intrinsically disordered'. They are contrary to the natural law. They close the sexual act to the gift of life. They do not proceed from a genuine affective and sexual complementarity. Under no circumstances can they be approved (CCC 2357).

At the same time, despite the unknown origin of homosexual inclinations, 'these persons are called to fulfil God's will in their lives and, if they are Christians, to unite to the sacrifice of the Lord's Cross the difficulties they may encounter from their condition' (CCC 2358). It is important to note the honest view of homosexual orientation by the authors of the Catechism of the Catholic Church. For example, homosexuality is not called a disease and it is acknowledged that its genesis is not yet known. Instead of a disease, the term 'disorder' is used. In this context it means that homosexual acts, from the theological point of view, are incompatible with the Creator's plan, the purposefulness of human sexuality and the dynamics of the bond which guarantees love in mutual devotion of persons. Biblical anthropology is based on the premise that God created man and woman, and it is between them that we speak of love, of which the sexual sphere is one of the essential elements. Therefore, the question of not allowing persons with homosexual inclinations to be ordained touches the sphere of human purity, which is backed up by a specific theology.

Joseph Ratzinger's position, which he took against Richard Egenter's article on compulsory celibacy, may help in grasping this general theological

${ }^{17}$ Cf. D. Oko, Lawendowa mafia ..., p. 185. 
understanding of the pledge of celibacy and chastity. According to the then Archbishop of Munich and Freising, celibates must not constitute 'an association of old bachelors'. ${ }^{18} \mathrm{He}$ argued that the celibacy of diocesan priests, which is not a common ecclesiastical formula but a private decision, loses its essential theological content and decisive personal support because it ceases to be a sign carried by the Church and becomes a private peculiarity. In such a situation, celibacy is no longer a significant abandonment in favour of ministry assumed in faith, but an oddity doomed to legitimate disappearance. ${ }^{19}$ These words - although written in the 1970s — can provide a theological background for the Holy See's decision not to admit people with a homosexual orientation to the sacrament of Holy Orders. In the case of such people, celibacy becomes indeed an 'oddity', it is not a renunciation at all, but becomes a way of turning the inclination - and sometimes even homosexual acts — into a virtue. Celibacy, therefore, according to the retired Pope, is a state of remaining unmarried that is meant to be a sign for the Church. Celibacy not lived as a sign and a sacrifice becomes a life of singles who are comfortable in a celibate state. A celibate life lived in this way becomes its negation and ceases to be a clear sign for Christians. It is precisely in the context of homosexual priests that the question arises whether their celibacy has not ceased to be intelligible to themselves and others, and finally, whether celibacy has not lost its expression at all. This question was already answered years ago by Gisbert Greshake in his well-known publication Priestersein/Being a Priest. He believes

the answer to this objection [to the illegibility of celibacy — author's note] is that $[\ldots]$ the sign [sacrament!] is essentially linked to the explanatory word. If, therefore, the communities were really not to understand the sign of celibacy, then preaching and catechesis should be seriously re-examined: how and how often is this sign explained? ${ }^{20}$

The ignorance of the meaning of priestly celibacy may concern the candidates for the priesthood themselves. If celibacy ceases to be a conscious, free and responsible decision of a man and becomes a convenient way of life, it is necessary to ask about the motive for choosing such a state of life. Such a wrong understanding of celibacy may affect not only presbyters with homosexual inclinations, but also heterosexual priests.

${ }^{18}$ Cf. J. Ratzinger, Opera omnia, vol. XII: Głosiciele Słowa i słudzy waszej radości, Lublin 2012 , p. 146.

19 Ibid., p. 145.

${ }^{20}$ G. Greshake, Być Kapłanem. Teologia i duchowość urzędu kapłańskiego, tłum. K. Wójtowicz, Wrocław 1983, p. 155. 
On the one hand, celibacy is to be a sign for the community of the Church and, on the other, it is to be an existential way of giving glory to God. ${ }^{21}$ It is in this context that the words of the Council of Trent should be understood: 'If anyone says that the married state excels the state of virginity or celibacy, and that it is better and happier to be united in matrimony than to remain in virginity or celibacy, let him be anathema'.$^{22}$ According to the Council Fathers, it was not a question of belittling marriage, which after all is also a sacrament, but of setting celibacy and virginity precisely in the context of marriage. Light is shed on the theology behind this statement of the Council of the Reformation era by the theology of priestly celibacy presented by the retired pope in the famous book written with Robert Sarah. According to Benedict XVI, the impossibility of reconciling the priestly state with marriage as in the Old Testament priesthood arose from the daily celebration of the Eucharist by Catholic presbyters. It can be said that sexual abstinence, which was linked to the exercised function, was itself transformed into ontological abstinence. ${ }^{23}$ Thus, the very life of the Catholic presbyter through its otherness was to point to Jesus Christ and His sacrifice. ${ }^{24}$ We should therefore analyse the problem from the perspective of sacramentology. The Eucharist, as the most holy sacrament, source and summit of Christian life, is the one to which other sacraments lead. The sexual discipline of ordinary ministers should therefore be related to the celebration of this sacrament. Early Christianity advised presbyters to abstain from sexual intercourse before celebrating the Eucharistic liturgy. This practice survives in modern Orthodoxy. Sexual abstinence is therefore closely related to the Divine ministry. For the theology of the sacraments or for their validity, it does not matter what sexual orientation a presbyter has, however, in Latin theology, the complete abstinence from any sexual activity is important, as it is first and foremost about complete dedication to Christ in the sacrament of Holy Orders. Sexual abstinence for Latin-Rite Catholic presbyters is grounded in the vow of celibacy, and this is where the problem of the presbyter's sexual identity may arise. Homosexuality in the context of the sacrament of Holy Orders is an issue which combines Christological, sacramental, moral and pastoral aspects. The doctrinal issue is crucial for the justification

${ }^{21}$ Cf. J. Królikowski, Powołanie, konsekracja i postanie. Z teologii świętego kapłaństwa, Kraków 2017, pp. 111-112.

${ }^{22}$ Sobór Trydencki, Nauka, kanony oraz inne sprawy dotyczace sakramentu matżeństwa (1563) [in:] Dokumenty Soborów Powszechnych. Tekst łaciński, polski, t. IV/2: Lateran V, Trydent, Watykan I, red. A. Baron, H. Pietras, Kraków 2007, s. 719.

${ }^{23}$ R. Sarah, Benedykt XVI, Z głębi naszych serc, tłum. A. Kuryś, Warszawa 2020, p. 39.

${ }^{24}$ It should be noted that even in communities in which celibacy is optional, candidates for episcopal ordination are chosen from among celibates. Thus, in these communities, the ancient tradition of celibacy understood as a life totally dedicated to the Lord and the Church has been preserved. 
of the other aspects, since it points to the sense of the presbyters' renunciation of having families of their own and thus, in the Latin ecclesial practice, to the vows of celibacy.

This theology of priestly celibacy, chastity and virginity is behind the ban on ordaining homosexual men. It is worth noting in this context that homosexual inclinations, like heterosexual orientation, constitute the person, motivate his decisions and choices. Celibacy in the Catholic understanding pledged by a homosexual would be a resignation from a life he would never have chosen anyway. The sign therefore ceases to be what it means.

\section{An Attempt at a Theological Evaluation}

That homosexuality can bear bad fruit when obscured by celibacy is shown, among others, by the report prepared and made available in 2020 by the Secretariat of State of the Holy See on the sexual abuse of the former cardinal and the former clergyman, Theodore McCarrick. ${ }^{25}$ It must be added that this document was produced at the express request of Pope Francis. That the problem addressed in this text is not a peripheral one is evidenced, for example, by the retired Pope's statement on homosexual cliques in the seminaries ${ }^{26}$ or by a small booklet by the American bishop, Robert Barron. ${ }^{27}$ The deep crisis of priestly identity is evidenced by the research of Daniel Cozzens - the former rector of the seminary in the Diocese of Cleveland. According to this research, the percentage of homosexuals among Catholic presbyters in the last hundred years has ranged from 23 to $58 \%$ and, as a result, the Catholic priesthood in the United States is identified with the so-called gay profession. ${ }^{28}$ Catholic theology, especially dogmatics, cannot be indifferent to all this information and should also seek theological and doctrinal solutions to contemporary problems. ${ }^{29}$

An example of this doctrinal-pastoral approach is the action called for by Benedict XVI in his letter to Catholics in Ireland following the paedophile scandals. In 2010, the Pope stated that

${ }^{25}$ The full text of this report in English can be found at: http://www.vatican.va/resources/ resources_rapporto-card-mccarrick_20201110_en.pdf [accessed: 12.2.2021].

${ }^{26}$ Cf. Benedykt XVI, List o przyczynach kryzysu w Kościele, Kraków 2019, p. 22.

${ }^{27}$ Cf. R. Barron, Letter to a Suffering Church: A Bishop Speaks on the Sexual Abuse Crisis, Park Ridge 2019.

${ }^{28}$ Cf. D. Cozzens, The Changing Face of the Priesthood: A Reflection on the Priest's Crisis of Soul, Minnesota 2000, p. 107.

${ }_{29}$ An example of a theologian's approach to these problems can be found in the excerpts from the book by Polish dogmatist Bogdan Ferdek: Logos nadziei. Camino jako laboratorium nadziei, Wrocław 2020, pp. 51-53. 
only by examining carefully the many elements that gave rise to the present crisis can a clear-sighted diagnosis of its causes be undertaken and effective remedies be found. Certainly, among the contributing factors we can include: inadequate procedures for determining the suitability of candidates for the priesthood and the religious life; insufficient human, moral, intellectual and spiritual formation in seminaries and novitiates; a tendency in society to favour the clergy and other authority figures; and a misplaced concern for the reputation of the Church and the avoidance of scandal, resulting in failure to apply existing canonical penalties and to safeguard the dignity of every person. ${ }^{30}$

The Pope Emeritus implies that we need to look for the genesis of the various crises of the Church. The causes of the paedophile scandals and the presence of homosexuals in the ranks of the Catholic clergy may be due to inadequate or ignored procedures at the time of the admission of candidates to the seminaries and due to a more lenient approach to clerical vices. If a candidate for the priesthood manifests homosexual tendencies, then his complete disinterest in the opposite sex will be perceived as a virtue or a special gift from God.

In this context, it is worth recalling the numerous paedophile scandals in the Church in the United States and Europe, which are linked to the homosexuality of those committing the crime. John Paul II in his 2002 address to the American bishops pointed out that

the abuse of the young is a grave symptom of a crisis affecting not only the Church but society as a whole. It is a deep-seated crisis of sexual morality, even of human relationships, and its prime victims are the family and the young. In addressing the problem of abuse with clarity and determination, the Church will help society to understand and deal with the crisis in its midst. ${ }^{31}$

In other words, John Paul II was therefore a proponent of addressing the problems of homosexuality and paedophilia among the clergy. However, some current demands to "extinguish the cult ${ }^{32}$ of the Pope from Poland do not take into account the fact that twenty years ago there was not even a language to talk

${ }^{30}$ Benedict XVI, Pastoral Letter of the Holy Father Pope Benedict XVI to the Catholics of Ireland (2010) 4, http://www.vatican.va/content/benedict-xvi/en/letters/2010/documents/hf_benxvi_let 20100319 church-ireland.html [accessed: 12.2.2021].

31 John Paul II, Address of John Paul II to the Cardinals of the United States (2002) 3, http:// www.vatican.va/content/john-paul-ii/en/speeches/2002/april/documents/hf_jp-ii_spe_20020423 usa-cardinals.html [accessed: 12.2.2021].

${ }^{32}$ Such a demand can be found, among others, on the website of the National Catholic Reporter: https://www.ncronline.org/news/accountability/editorial-us-bishops-please-suppresscult-st-john-paul-ii [accessed: 12.2.2021]. 
openly about homosexuality in priestly ranks. Rather, an awareness of the consequences of sexual abuse and the role of the clergy in committing and covering up these crimes was only just emerging.

It is also noteworthy that in the situation of announcing the prohibition of ordination for homosexuals, the proper relationship between logos (the doctrine of the Church) and ethos (the introduction of concrete solutions) was preserved. This was clearly shown by the Australian theologian, Tracey Rowland. According to her, ethos should stem from logos and not the other way round. Canon law and pastoral practice must not stand in opposition to the doctrine of the Church, but rather stem from it. ${ }^{33}$ For if ethos precedes logos, then the Holy See should not only allow homosexuals to receive the sacrament of Holy Orders, but also accept homosexual inclinations and acts as compatible with the spirit of the Gospel.

It is no accident that the contemporary Vatican documents banning the ordination of homosexuals should be read in the context of the Church's teaching on chastity. The purity of the priest is linked to the purity of Jesus Christ, to whom the presbyter is particularly bound through the sacrament of Holy Orders. Therefore, it can be said that the Church links sacramentology, moral theology and law with Christology. This is well illustrated in the 1986 document of the Congregation for the Doctrine of the Faith Homosexualitatis problema. The authors of the document state:

What, then, are homosexual persons to do who seek to follow the Lord? Fundamentally, they are called to enact the will of God in their life by joining whatever sufferings and difficulties they experience in virtue of their condition to the sacrifice of the Lord's Cross. That Cross, for the believer, is a fruitful sacrifice since from that death come life and redemption. ${ }^{34}$

Also priests with homosexual tendencies are called to chastity. Benedict XVI mentioned it as a problem of the contemporary Church in a conversation with Peter Seewald. He encouraged homosexual priests to try not to practice their inclinations and to remain faithful to their vows. ${ }^{35}$

In assessing the Church's position on the ordination of men with persistent and deep-seated homosexual inclinations, it should be noted that although this problem has existed for centuries, the Church's awareness of its importance has only emerged relatively recently. No doubt the sex scandals have contributed to building this awareness. Obviously, this does not mean that theology suggests a simple

${ }_{33}$ Cf. T. Rowland, Catholic Theology, London 2017, p. 34.

${ }^{34}$ The Congregation for the Doctrine of the Faith, Letter to the Bishops of the Catholic Church on the Pastoral Care of Homosexual Persons Homosexualitatis problema (1986) 12, https://www. vatican.va/roman_curia/congregations/cfaith/documents/rc_con_cfaith_doc_19861001_homosexual-persons_en.html [accessed: 12.2.2021].

${ }^{35}$ Cf. Benedict XVI, P. Seewald, Light of the World..., p. 151. 
link between homosexuality and paedophilia, but it does point to a disorder that can lead to inappropriate relationships with others entrusted to pastoral care.

\section{Final Conclusions}

The cases of homosexual men who have received the sacrament of Holy Orders are an example of a divergence of doctrine and pastoral practice and one of the many causes of the Church's contemporary crisis. It can be argued that although on the doctrinal ground Catholic teaching has retained its coherence, at the level of its reception this teaching has been treated as a mere suggestion. Vatican documents since the beginning of the $21^{\text {st }}$ century specify that the sacrament of Holy Orders should not be conferred on men not only who practice their homosexuality, but also on those who, despite their homosexual inclinations, do not do so. The inclinations themselves are therefore an obstacle to ordination. According to Pope Emeritus, a priesthood that ceases to be a service to the faith and instead becomes a place for concealing homosexual orientation has lost God from its horizon. Therefore, during the prefecture held by Joseph Ratzinger, the problems of cases of homosexuality among candidates for the priesthood and sexual abuse of minors were transferred to the Congregation for the Doctrine of the Faith. The designation of this institution to it was also meant to be a signal that for the Church it is a top priority - said Pope Emeritus in an interview with Peter Seewald. ${ }^{36}$ In other words, the crisis over the homosexuality of some clergy strikes at the very heart of priesthood, which is the authentic transmission of the Church's faith.

The theology behind these decisions is the Church's centuries-old teaching on chastity. On the one hand, it boils down to the fact that a homosexual person, by pledging to remain celibate, does not in fact renounce marriage. This pledge becomes an illegible sign for the Church as well as for the presbyter himself. On the other hand, celibacy becomes fully legible only in the context of the theology of marriage, and moreover, in the light of Christology. The relationship of the presbyter to the celebration of the Eucharist is manifested in his life, among other things, in his vow of celibacy, which must be undertaken as an expression of reverence for the Mystery which is celebrated in the Church in liturgical rites. The doctrine is therefore followed by morals and pastoral solutions. When evaluating the decisions of the Holy See and the theology behind them, it is worth noting that in this case it was not praxis that determined theology, but theology determined concrete solutions. The issue of the reception of these decisions of the Church and the clear presentation of her teaching may become a remedy for the crisis afflicting Christianity in the $21^{\text {st }}$ century.

${ }^{36}$ Cf. Benedict XVI, P. Seewald, Ostatnie rozmowy, tłum. J. Jurczyński, Kraków 2016, p. 234. 


\section{Wybrane argumenty doktrynalne przeciwko dopuszczaniu do sakramentu święceń osób o orientacji homoseksualnej}

\section{Streszczenie}

Problem poruszany w niniejszym artykule brzmi: jakie doktrynalne argumenty stoją za aktualną decyzją Stolicy Apostolskiej o niedopuszczaniu do sakramentu święceń mężczyzn o trwale zakorzenionej orientacji homoseksualnej. Trzyetapowa droga do rozwiązania problemu przebiega następująco: przez ukazanie wybranych treści dokumentów Stolicy Apostolskiej w XX i XXI wieku, prezentację doktrynalnych wątków tam obecnych i próbę oceny ich recepcji w świetle aktualnych wyzwań. Autor odwołuje się do dokumentów Stolicy Apostolskiej oraz wypowiedzi papieży.

\section{Słowa kluczowe}

kapłaństwo, homoseksualizm, celibat, doktryna

\section{Keywords}

priesthood, homosexuality, celibacy, doctrine

\section{Bibliography}

Barron R., Letter to a Suffering Church: A Bishop Speaks on the Sexual Abuse Crisis, Park Ridge 2019.

Benedict XVI, Pastoral Letter of the Holy Father Pope Benedict XVI to the Catholics of Ireland (2010), http:/www.vatican.va/content/benedict-Xvi/en/letters/2010/documents/hf_ben-xvi_let_20100319_church-ireland.html.

Benedykt XVI, List o przyczynach kryzysu w Kościele, Kraków 2019.

Benedict XVI, Seewald P., Light of the World: The Pope, the Church and the Signs of the Times, San Francisco 2010.

Benedykt XVI, Seewald P., Ostatnie rozmowy, tłum. J. Jurczyński, Kraków 2016.

Beyga P., Tradycja anglikańska $w$ mszale dla ordynariatów personalnych bylych anglikanów, Opole 2018.

Bruncz D., Wspólnota anglikańska po Konferencji Lambeth 2008, "Studia i Dokumenty Ekumeniczne" 63 (2008) 2, pp. 81-93.

Chiron Y., Rewolucja 68. Swąd szatana w Kościele, tłum. M. Żurowska, Kraków 2021.

Cozzens D., The Changing Face of the Priesthood: A Reflection on the Priest's Crisis of Soul, Minnesota 2000.

Ferdek B., Logos nadziei. Camino jako laboratorium nadziei, Wrocław 2020.

Greshake G., Być Kapłanem. Teologia i duchowość urzędu kapłańskiego, tłum. K. Wójtowicz, Wrocław 1983. 
John Paul II, Address of John Paul II to the Cardinals of the United States (2002), http:// www.vatican.va/content/john-paul-ii/en/speeches/2002/april/documents/hf_jp-ii spe_20020423_usa-cardinals.html.

Kobyliński A., Homoseksualizm i kapłaństwo w Kościele katolickim na przestrzeni wieków, "Przegląd Historyczny" 109 (2018) 2, pp. 283-309.

Królikowski J., Powołanie, konsekracja i posłanie. Z teologii świętego kapłaństwa, Kraków 2017.

Nadbrzeżny A., Unia czy wspólnota z Rzymem? Pytanie o model jedności chrześcijan w konstytucji apostolskiej Benedykta XVI "Anglicanorum coetibus", "Studia Salvatoriana Polonica" 4 (2010), pp. 39-51.

Napiórkowski A., Między ekumenizmem a konwertyzmem. Kościót rzymskokatolicki a Kościół anglikański [in:] Dialog ekumeniczny a missio Ecclesiae, red. M. Chojnacki, J. Morawa, A. Napiórkowski, Kraków 2011, pp. 33-59.

Oko D., Lawendowa mafia. Z papieżami i biskupami przeciwko homoklikom w Kościele, Kraków 2020.

Pietras H., Dymisja ze stanu duchownego i jej skutki w starożytności chrześcijańskiej [in:] Odejścia od kapłaństwa. Studium historyczno-psychologiczne, red. K. Dyrek, Kraków 2010, pp. 7-19.

Piotr Damiani, Księga Gomory [in:] K. Skwierczyński, Piotra Damianiego „Księga Gomory" i walka z sodomiq wśród kleru, Kraków 2011, pp. 257-309.

Pius V, The Bull Horrendum illud scelus (1568), https://www.rkdocumenten.nl/rkdocs/ index.php? $\mathrm{mi}=600 \& \mathrm{doc}=7021$.

Ratzinger J., Opera omnia, vol. XII: Gtosiciele Stowa i studzy waszej radości, Lublin 2012.

Rowland T., Catholic Theology, London 2017.

Sacred Congregation For Religious, Instruction on the Careful Selection And Training Of Candidates For The States Of Perfection And Sacred Orders Religiosorum Institutio (1961), https://www.papalencyclicals.net/john23/j23religios.htm.

Sarah R., Benedykt XVI, Z głębi naszych serc, tłum. A. Kuryś, Warszawa 2020.

Secretariat of State of the Holy See, Report on the Holy See's Institutional Knowledge and Decidion Making Related To Former Cardinal Theodore Edgar McCarrick (1930 to 2017), Vatican City State 2020. http://www.vatican.va/resources/resources rapporto-card-mccarrick_20201110_en.pdf.

Sobór Trydencki, Nauka, kanony oraz inne sprawy dotyczace sakramentu matzeństwa (1563) [in:] Dokumenty Soborów Powszechnych. Tekst łaciński, polski, t. IV/2: Lateran V, Trydent, Watykan I, red. A. Baron, H. Pietras, Kraków 2007, pp. 715-732.

The Congregation for Catholic Education, Instruction Concerning the Criteria for the Discernment of Vocations with regard to Persons with Homosexual Tendencies in view of their Admission to the Seminary and to Holy Orders (2005) http://www. vatican.va/roman_curia/congregations/ccatheduc/documents/rc_con_ccatheduc doc_20051104_istruzione_en.html. 
The Congregation for Institutes of Consecrated Life and Societies of Apostolic Life, Directives on Formation in Religious Institutes Potissimum Institutioni (1990), https://www.vatican.va/roman_curia/congregations/ccscrlife/documents/rc_con ccscrlife_doc_02021990_directives-on-formation_en.html.

The Congregation for the Doctrine of the Faith, Letter to the Bishops of the Catholic Church on the Pastoral Care of Homosexual Persons Homosexualitatis problema (1986). https://www.vatican.va/roman_curia/congregations/cfaith/documents/rc con_cfaith_doc_19861001_homosexual-persons_en.html. 